\title{
Intellectual Potential as a Factor in Achieving the Socio-Economic Purposes of the Territory Development
}

\author{
Natalia Tregulova*, Marina Bugaeva \\ Institute of Service and Business (branch) of Don State Technical University in Shakhty, Shahty, Russia \\ ${ }^{*}$ Corresponding author. Email: ntregulova@mail.ru
}

\begin{abstract}
The globalization of the modern economy entails not only progressive changes and scientific and technological breakthroughs, but also the inevitability of crisis phenomena. In this regard, innovation activity and its basis intellectual potential, i.e. a certain stock of achievements, knowledge and experience, acquire special value. Each region chooses its own direction in its development, this is due, of course, to individual factors, but the determining factor is the intellectual potential of the territory, the degree of development of which determines whether the region can achieve innovative development that affects the production level of the entire country. The article studies the intellectual potential of the subject of the Russian Federation by determining the prevailing sectors of the economy and the needs of their development. A comprehensive analysis of an important social and economic indicator is defined, which is a theoretical and practical tool for choosing a strategy for the development of the intellectual potential of a particular region. By comparing the resources of different regions, the need for an exceptionally rational choice of a particular industry was proved. An important social and economic indicator was studied, which contributes to the rational choice of the development of the region, based on the intellectual potential of the territory and the intellectual capacity of employees.
\end{abstract}

Keywords: intellectual potential, territory, development, human potential.

\section{INTRODUCTION}

A correct understanding of the nature of a particular region has a fruitful impact on its development, since it is impossible to demand cultural and research activities from a predominantly innovative and industrial region. It is quite problematic to develop the intellectual potential of the region in the field of, for example, digital technologies, while developing agriculture or tourism in the territory to a greater extent. It is important to take into account the resources and characteristics of the territory when developing its intellectual potential. Thus, an incorrect redistribution or financial investment can lead to: low turnover of the relevant and working sphere in a particular region and, of course, the ineffectual use of funds. Intellectual potential is a tool not only for socioeconomic analysis, but also for organizational management of financial and investment activities that determine the most profitable and effective areas of investment in a particular region. When determining the practical importance of this institution, there is a need for its theoretical component: the definition of the term, the nature of its origin, and the study of primary sources.

The impact of human intelligence on the development of the economy is difficult to overestimate. It is no coincidence that many researchers have paid great attention to this phenomenon in their works. These include J. Galbraith, who in the second half of the XX century formulated the concept of intellectual potential. In a letter to M. Kalecki in 1969, the scientist associated this concept with "intellectual activity" [1]. The scientific literature considers two similar, but not identical, definitions: potential and capital. For further study, it is necessary to determine which activity is the basic one for each of them. "Intellectual capital" is interpreted as the totality of human abilities and the possibility of their optimal application. Whereas "intellectual potential" refers to the use by an economic entity of its reserves and opportunities in the field of interest. T. Stewart in 1991 formulated the definition of intellectual capital as the sum of all the knowledge of the company's employees: "... 
patents, processes, management skills, technologies, experience and information about consumers and suppliers". Combined together, this knowledge increases the competitiveness and economic efficiency of the firm. In turn, V. M. Shepelev considers the potential in the context of the probabilistic possibilities of the subject's activity in certain circumstances. It assigns a crucial role to the impact on the staff. According to its concept, in order to improve the efficiency of the enterprise, it is necessary not only to study and improve the level of knowledge and professional competencies of employees, but also to apply modern management strategies, create new conditions for the maximum disclosure of human capabilities.

So, the most important contribution to the study of this issue, in our opinion, was made by T. Stewart, since he defined "intellectual potential" as the sum of all skills, and V.M. Shepelev, since, in his works, the role of the subject in the management of existing intellectual capabilities was outlined. Based solely on the content of the above works, it is possible to formulate a definition of "intellectual potential" but it is already applicable to the territory. Thus, "intellectual potential" can be understood as a set of opportunities, potential, resources, and the relevant conditions of the region, but this concept also includes the organizational and analyzing activities of the authorized entity for the rational and effective management of the opportunities available in a particular region. In our opinion, the content of the "intellectual potential of the territory" requires, as T. Stewart pointed out, "the most valuable asset", i.e., employees, subjects with certain knowledge and skills that realize the potential of the region. So, these are clearly numerous and interrelated components that create and multiply intellectual potential by their actions. In the future, it is necessary to give the officially existing definition. Loseva O. V. in her understanding and theoretical justification of the definition of "intellectual potential" also confirms the validity and relevance of the definitions given above. In addition, it includes two interrelated components in the term. First, it is the resource potential, which represents the mental abilities of the staff, their accumulated professional experience, creativity, and unconventional thinking. Secondly, it is the potential of the conditions created in the region to maximize the potential of the staff.

\section{MATERIALS AND METHODS}

The materials for the study were economic statistics, scientific and other literature on personnel management, periodicals, data from statistical collections, as well as materials from official sources on the Internet. The quantitative data of the sources of the formation of the intellectual potential of the region, and the indicators that form the reserve for the development of the intellectual potential of the region (Rostov region) were analyzed.
The analysis of the level and prospects for the development of the intellectual potential of the region and the identification of prospects for industries and areas of intellectual potential development is carried out using such methods of scientific knowledge as:

- historical research method-was used in the study of the prerequisites for the emergence of the definition of "intellectual potential";

- statistical method of research. This method, along with the synthesis method, allowed us to collect and summarize the information received about the state of the issue, i.e., about the prospects for the development of the intellectual potential of the region and to understand the vectors of the development of the region in this way;

- graphic method. This method was used in the work in the greatest way, which allowed us to formulate a methodology for assessing the innovative potential of the region and to show graphically an algorithm for identifying the prospects of industries and areas of development of the intellectual potential of the Rostov region, which will allow us to convey information to the reader as effectively as possible.

The study was conducted on the example of the Rostov region. The data for the study were taken for 2020-2021.

The main hypothesis of the study: the development of the intellectual potential of the region should be based on the development of economic sectors that represent the intellectual core of the region, which will significantly increase the effectiveness of actions to achieve the socioeconomic challenges of the development strategy of the region and the country as a whole.

\section{RESULTS}

After determining the theoretical component of the studied economic and organizational institution, the definition of the intellectual potential of the region becomes a primary task, since the identification of the two above-mentioned components, first of all, allows for the rational use of forces and means, paying attention to the actual existing opportunities, and not "imaginative representations of a particular consequence, when using a certain type of resource". Secondly, the definition of the above components allows you to quickly influence the inefficient or undeveloped potential of a particular region by identifying the problem area. In the future, an important theoretical issue is the choice of a strategy for the development of the intellectual potential of the Rostov region, the preference of which depends on the development of certain enterprises that are of the greatest interest to the region. The following approaches to the assessment of the intellectual potential of the region, i.e. the strategy, were identified: 
1. Production-industry approach. Within the framework of this approach, the prospects and opportunities of the leading economic sectors of the region are analyzed and evaluated. For each industry, indicators are developed that determine its effectiveness and the value of its contribution to the gross regional product.

2. Statistical approach. The disadvantages include insufficient consideration of the specific features of a particular region.Thus, after the above hypotheses, we can conclude that the second concept is "incentive" in nature, since it is not aimed at the development of a specific industry that distinguishes a particular region, but involves the maintenance and implementation of common resources that are not individual in nature.

The Southern Federal District is represented by numerous subjects, each of which has distinctive properties, but none of them contains city-forming enterprises. This implies the choice of a universal concept and the setting of appropriate tasks for enterprises. For example, Rostov-on-Don has a fairly developed cultural and educational environment, which explains the numerous schools and universities, where among the latter there is the Southern Federal University, the Don State Technical University, the Rostov State University of Economics and others.

For a more complete study of the state of the cultural and educational environment, we will analyze the educational environment that contributes to the development of the intellectual potential of the region. In total, there are 67 universities, 47 youth scientific associations, 55 councils of young specialists, and 13 organizations of young scientists in the Rostov Region. At the level of departments, faculties and laboratories, there are more than 250 youth research teams. Since 2009, the Council of Young Scientists and Specialists has been operating under the Government of the Rostov Region. But this does not imply competition with other regions that specialize exclusively in scientific and educational activities. So the following subjects of the Russian Federation will stand out: Kaluga, Nizhny Novgorod, Tambov, Tver, Vladimir, Yaroslavl, Moscow region, which have more extensive potential in this area than the Rostov region [2].

Thus, the educational activities of the Southern Federal District and the Rostov Region are aimed exclusively at maintaining the existing resources and providing the social infrastructure of the city, thereby complying with the established strategy and the corresponding tasks $[3,4]$. When answering the question "What determines the intellectual potential" of the region, in our opinion, we should be guided by the initial strategy, since it determines the type of region, potentials and resources, unique or widespread.
In connection with the entry into force of the Strategy of Scientific and Technological Development of the Russian Federation and the Program "Digital Economy of the Russian Federation", the task was set for the regions and the country to enter a new innovative stage of development, including to make digital transformations in all spheres of activity of the population of the regions and the country as a whole [5]. During the Covid 19 coronavirus pandemic, the entire country was forced to switch to a remote format in educational and professional activities, which created the need to adapt digital technologies in a short time. However, in the current situation, the labor market has also changed, creating a need for personnel who have mastered digital competencies, which directly affects the vector of development of the intellectual potential of the Rostov region [2].

Continuing the analysis of the activities of Rostov-onDon, it is necessary to determine the priority sectors that are developing on the basis of the existing potential, namely, soil resources [6]. So it is agricultural activity that is the prerogative of the Rostov region, earlier it was determined that there was no "competition" in the field of educational and cultural activities with others, but in the field of agriculture, the Rostov region occupies one of the leading positions, which is provided by the resource needs of society and various economic enterprises. For example, providing food products to markets and shops, agricultural fairs, etc. The cultivated grain crops are widely used by livestock enterprises, which are also common in the Rostov region. Thus, agriculture is the predominant "core" of the strategy, resulting in the development of related industries: animal husbandry, crop production, gardening. The following indicators of the volume of investments in the Rostov region confirm the "special" attention aimed at the development of the agricultural sector: annual investments in the agricultural sectors of the Rostov region amount to about 30 billion rubles. It is obvious that without state support, this industry did not receive such a volume of investments. Thanks to the grant support, 11 new farms were created. By studying the official website of the Government of the Rostov region, the following state of agricultural activity was determined: the share of agriculture in the Rostov region in the Russian production of agricultural products is $5 \%$, and in the Southern Federal District $-30 \%$, i.e. we refer the agricultural sector to the priority sectors of the economy [1]. In addition to agriculture, the following priority clusters are registered here [7]:

— innovative cluster "Don Dairy products" for the production and processing of dairy products;

- road cluster;

— innovation and technology cluster "Southern Constellation"; 
— innovative territorial cluster of marine instrumentation "Marine Systems"; cluster;

- Information and communication technology

- national industrial cluster of agricultural engineering;

- Volgodonsk Industrial Cluster of Nuclear Engineering;

— territorial cluster "Don Valley".

\section{DISCUSSION}

The research made it possible to identify the intellectual core of the region, which consists of clusters of the region, large enterprises and priority sectors of the economy. So, the listed clusters of the region are also the intellectual core, so they are of interest for studying [8]. Thus, the Rostov region needs to develop the intellectual potential of the agricultural, transport, digital, information and communication, educational, food, scientific, technical and instrument-making spheres for the full development of the contained resources. That is, it is important for educational institutions of secondary special and higher education to prepare graduates with competencies, knowledge and skills in the listed priority areas of activity of the Rostov region. Despite the studied components of the intellectual potential of the territory, consisting of two components, the structure of the "intellectual potential" is much broader and consists of the following elements (Drawing 1).

The elements of intellectual potential are presented as follows:

- human potential. This element duplicates one of the components of the intellectual potential, since the implementation of the resources of the region requires the necessary professional skills and knowledge. Every region needs labor personnel, and in this regard, the question arises about the quality characteristics. The question "What kind of people do the region need" can be answered with certainty, it requires professionals in their field who have not widespread knowledge from the textbook. We need people who understand the" intellectual nature " of the region, and the basic needs of its implementation.

- organizational capacity. At the beginning of the study, we independently defined the term intellectual capital, where we put forward the assumption that the components of the intellectual potential of the territory, an organizational entity that exercises general management over the activities of the enterprise and embodies the resources of the region in their activities. After studying the relevant literature, this hypothesis was rejected, but in this structure, the organizational potential is important. In

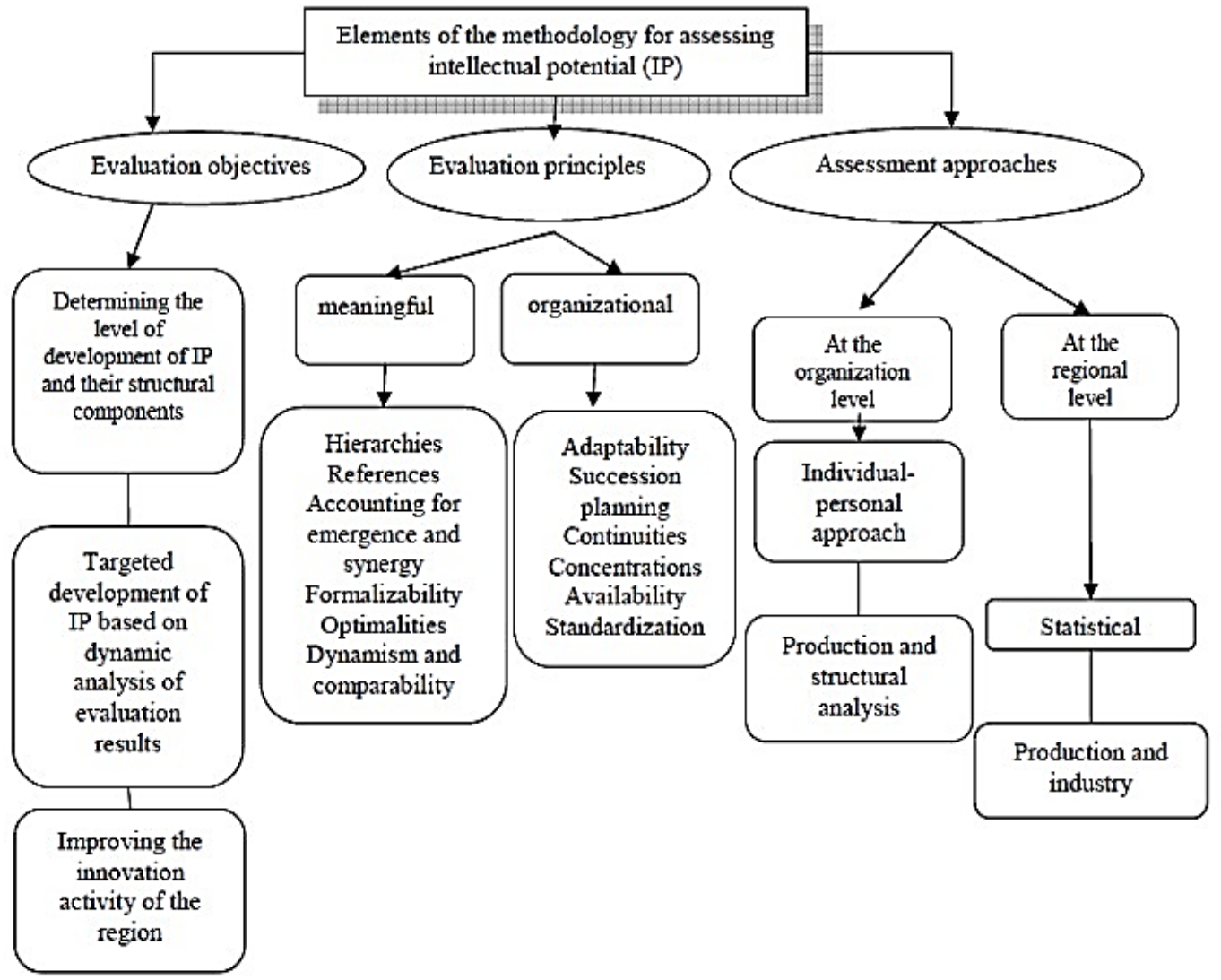

Figure 1 Elements of the methodology for assessing intellectual potential 
our opinion, this element is not only a control, but also a link between the resource capabilities of the region and the intellectual capabilities of the region [9-11].

- information potential. As S.E. Egorova and N.G. Kulakova point out, this is the relationship between conditions and resources, i.e. the use of accumulated knowledge and skills, their improvement, on the one hand, and the possibility of developing innovations, on the other [12].

- competitive potential. As with economic enterprises, competition has a fruitful effect on the use of innovations, new technologies, etc. In our opinion, such a factor cannot be excluded in relation to the region. For example, to increase the indicators of agricultural development in one region, in relation to another, it is possible to use innovations in agricultural machinery, etc. The need for such an application arises in connection with the emergence of the competitiveness factor.

the investment potential lies not only in the material financing of the industry or their combination, but also determines the solvency of the region, which also reflects its economic condition. The material component of any activity has a special aspect, since full and timely

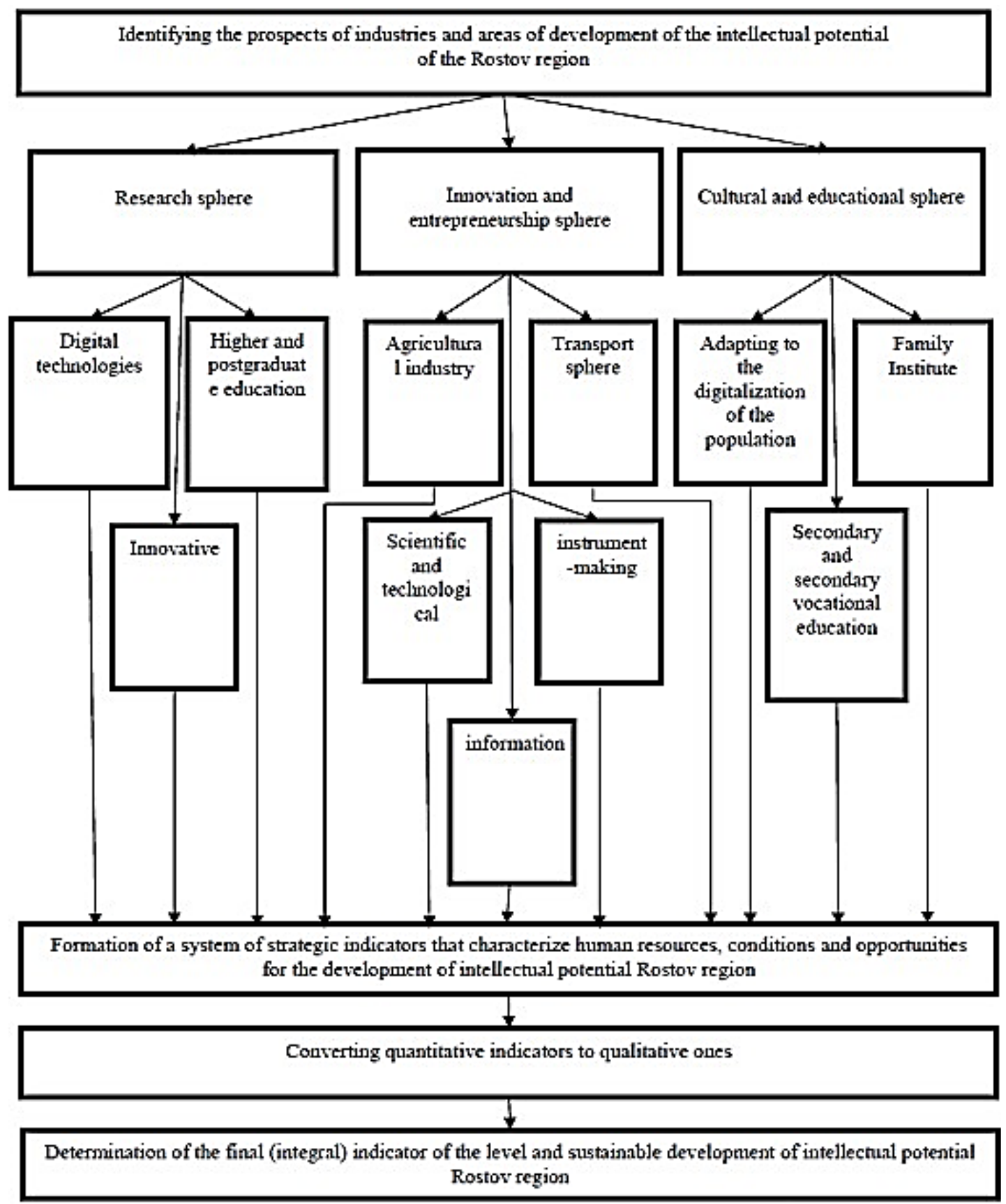

Figure 2 The model of statistical assessment of the intellectual potential of the region based on the identified priorities of its development 
Table 1. Indicators for assessing the intellectual potential of the Rostov region.

\begin{tabular}{|c|c|c|}
\hline $\begin{array}{l}\text { The sphere of intellectual } \\
\text { potential development of the } \\
\text { Rostov region }\end{array}$ & $\begin{array}{l}\text { Indicators for assessing the achieved level of } \\
\text { intellectual potential of the region }\end{array}$ & Calculation method \\
\hline \multirow[t]{5}{*}{$\begin{array}{l}\text { 1. Innovation and } \\
\text { entrepreneurship sphere }\end{array}$} & $\begin{array}{l}\text { Innovative products and services }\left(Q_{i}\right) \text { in the total } \\
\text { volume of goods and services shipped }(\mathrm{Q})\end{array}$ & $R_{1}=\frac{Q_{i}}{Q} \cdot 100 \%$ \\
\hline & $\begin{array}{l}\text { Income of the population from business activities }\left(\mathrm{P}_{\mathrm{ba}}\right) \\
\text { in the total amount of cash }(\mathrm{P})\end{array}$ & $R_{2}=\frac{P_{b a}}{P} \cdot 100 \%$ \\
\hline & $\begin{array}{l}\text { Organizations that implement organizational, } \\
\text { technological, or marketing innovations (Oi), to the } \\
\text { total number of organizations surveyed for the entire } \\
\text { period }(\mathrm{O})\end{array}$ & $R_{3}=\frac{O i}{O} \cdot 100 \%$ \\
\hline & $\begin{array}{l}\text { Advanced innovative technologies used (AITu) per } \\
1000 \text { people of the economically active population }\end{array}$ & $R_{4}=\frac{A I T_{u}}{S_{\text {eap }}} \cdot 100 \%$ \\
\hline & Investments in innovations, thousand rubles & $V_{i}=\sum I$ \\
\hline \multirow[t]{2}{*}{$\begin{array}{l}\text { 2. Cultural and educational } \\
\text { sphere }\end{array}$} & $\begin{array}{l}\text { Employees who have completed additional training, } \\
\text { advanced training, internship, from among the } \\
\text { economically active population }\end{array}$ & $R_{5}=\frac{S_{a t}}{S_{\text {eap }}} \cdot 100 \%$ \\
\hline & $\begin{array}{l}\text { Employee training costs related to the development } \\
\text { and use of information and communication } \\
\text { technologies (ICT) in the total amount of ICT costs }\end{array}$ & $R_{6}=\frac{S_{t}}{S_{i c t}} \cdot 100 \%$ \\
\hline \multirow[t]{3}{*}{ 3. Research sphere } & $\begin{array}{l}\text { Personnel engaged in research and development in the } \\
\text { economically active population }\end{array}$ & $R_{7}=\frac{S_{r}}{S_{\text {eap }}} \cdot 100 \%$ \\
\hline & Research associates with academic degrees & $R_{8}=\frac{S_{a d}}{S_{\text {eap }}} \cdot 100 \%$ \\
\hline & $\begin{array}{l}\text { Organizations that train postgraduates and doctoral } \\
\text { students }\end{array}$ & $V_{d s}=\sum O P_{d s}$ \\
\hline
\end{tabular}

financing allows you to plan activities, but also in some industries, a successful organization is impossible and monetary support is necessary in the shortest possible time. In this regard, such a resource as the "provision of subsidies from the budget" is of a social, economic and regulatory personality [13].

1) The social direction is implemented by performing the function of the state to provide material assistance in accordance with the Decree of the Government of the Russian Federation "About granting subsidies" №761 dated December 14, 2005, 88-FL "About supporting small and medium-sized businesses" dated 14 June 1995, 209- FL "On the development of small and medium-sized businesses" dated July 24, 2007. The social function is traced in the definition and payment of subsidies.

2) The definition of the economic nature does not require a detailed explanation, since the support of enterprises that develop the main industries of a particular region supports not only the development of economic potential, but also the implementation of the internal resources of the region, which supports the chosen strategy for the implementation of the intellectual potential of the territory.
3) The regulatory nature is determined by the ability of a particular region, through the provision of subsidies, payments.

The resource component of the intellectual potential of the region is the aggregate potential of organizations located on its territory [14]. Of particular value are organizations that have a high probability of forming scientific and technical or industrial clusters [15]. In our opinion, this term is called "core", since a certain enterprise concentrates around itself a wide network of others, usually having a contiguous character "with the center", and the region, provides organizational and financial assistance in their construction. So, for example, the Rostov region, whose main strategy is agriculture, where the "intellectual core" will be "Rostselmash", which directly produces agricultural machinery and all the clusters available on its territory. Having identified the priority areas for the development of the intellectual potential of the region, we will form a model for statistical assessment of the intellectual potential of the region (Drawing 2).

According to the model shown in the figure 2, we propose indicators for assessing the intellectual potential, 
with the help of which it will be possible to determine the level of the intellectual potential of the region in the future (table 1).

In our opinion, the intellectual potential of the Rostov region is defined as a resource, since:

1) the main opportunities, potentials, abilities of the Rostov region are in "fertile soils", as a result of which, as the main strategy for the development of intellectual potential, agriculture was identified;

2) the intellectual potential of the Rostov region cannot be defined as "intellectual", since agriculture is engaged in the production of exclusively resources that ensure the functioning of such areas as: animal husbandry, horticulture, crop production, which exclude intellectual orientation;

3) the "intellectual core" of the Rostov region, through the conducted research, was identified as "Rostselmash", engaged in the production of heavy agricultural machinery, and not a scientific center, educational institution, etc.;

the final argument is the presence in the Rostov region of numerous economic enterprises "collective farms" engaged in the collection and processing of "harvest", and not scientific activities.

\section{CONCLUSION}

As a result of the study, a comprehensive analysis of an important social and economic indicator was determined, which represents the theoretical and practical tools for choosing a strategy for developing the intellectual potential of a particular region. By comparing the resources of different regions, the need for an exceptionally rational choice of a particular industry was proved, since an erroneous definition leads to the depletion of the resource and financial capabilities of the region.

"Intellectual potential" as a scientific term, has undergone a long theoretical development by comparing scientific opinions. As a result, he acquired practical tools in the form of a strategy that provides for the presence or absence of unique opportunities in the region, so scientists have fixed the following types of strategies (approaches): "Production-industry "and "Statistical approach". The strategic choice is interdependent with the production tasks of the enterprises of the corresponding region, which was determined by comparing the Rostov region, which has no scientific and cultural potential, and the cities of different regions with an exclusively scientific and educational direction.

Also, based on the analysis that allowed us to identify the vectors of intellectual potential development, it can be argued that the Rostov region needs to develop the intellectual potential of agricultural, transport, digital, information and communication, educational, food, scientific and technical and instrument-making spheres for the full development of the contained resources. That is, it is important for educational institutions of secondary special and higher education to prepare graduates with competencies, knowledge and skills in the listed priority areas of activity of the Rostov region.

Within the framework of the conducted research, an important social and economic indicator was studied, which contributes to the rational choice of the development of the region, based on the intellectual potential of the territory and the intellectual capabilities of employees. Economic development is an important component of society, and it also implies the realization of constitutional human and civil rights. Thus, each region needs rational economic development, which provides intellectual potential.

\section{REFERENCES}

[1] E. Rudskaia, I. Eremenko, Digital clustering in customer relationship management, In: E3S Web of Conferences, 2019. DOI: https://doi.org/10.1051/e3 sconf/201913504010.

[2] V. Mazur, K. Barmuta, S. Demin, E. Tikhomirov, M. Bykovskiy, Innovation clusters: Advantages and disadvantage. International Journal of Economics and Financial Issues 1 (2016) pp. 270-274.

[3] N. Zaitseva, A. Larionova, O. Skrobotova, S. Trufanova, E. Dashkova, The mechanism of business integration and the training system for the tourism industry. Mathematics Education 6 (2016) pp. 1713-1722.

[4] M. Gureva, S. Lyubimtseva, T. Tukhkanen, O. Lyubimtseva, L. Simonova, E. Kolpak, Functioning of innovative territorial clusters. International Journal of Economics and Financial Issues 8 (2016) pp. 115-120.

[5] A. Tatuev, N. Kiseleva, E. Lyapuntsova, V. Rokotyanskaya, N. Valuiskov, Need of the market principles of development of the economic relations for the sphere of educational services. Social Sciences (Pakistan) 10 (2016) pp. 2515-2521. DOI: https://doi.org/10.3923/sscience.2016.2515.2 521.

[6] S. Kireev, I. Litvinenko, M. Zelinskaya, A. Arutyunova, S. Fateva, V. Shcherbakov, Economic clusters: Concepts and characteristic features. International Journal of Applied Business and Economic Research 13 (2017) pp. 123-132.

[7] E. Popkova, K. Zmiyak, Priorities of training of digital personnel for industry 4.0: social competencies vs technical competencies. On the 
Horizon 27 (2019) pp. 138-144. DOI: https://doi.org/10.1108/OTH-08-2019-0058.

[8] T. Tolstykh, D. Savon, A. Safronov, E. Shkarupeta, T. Ivanochkina, Economic transformations based on competence approach in the digital age, In: Proceedings of the 32nd International Business Information Management Association Conference, IBIMA 2018 - Vision 2020: Sustainable Economic Development and Application of Innovation Management from Regional expansion to Global Growth, 2018, pp. 7723-7729. DOI: https://doi.org/10.35808/ersj/1165.

[9] S. Vasenev, N. Ovanesyan, M. Rossinskaya, S. Volgina, V. Rokotyanskaya, Crisis management of regional development: Cluster initiatives in Russia and their efficiency. Journal of Advanced Research in Law and Economics 2017 pp. 644-657.

[10] I. Chizhankova, N. Novikova, E. Povorina, E. Duplij, I. Androsova, Clusters in the system of interindustry regional integration. International Journal of Applied Business and Economic Research 13 (2017) pp. 23-30.

[11] D. Shkurkin, E. Kolpak, T. Kormiltsyna, N. Novoselova, Regional clusters in the strategy of achieving technological leadership. International Journal of Applied Business and Economic Research 15(13) (2017) pp. 171-177.

[12] S. Krymov, I. Kapustina, M. Kolgan, Management system business process as a model for the training of industrial enterprises, In: Proceedings of 2017 IEEE 6th Forum Strategic Partnership of Universities and Enterprises of Hi-Tech Branches (Science. Education. Innovations). SPUE 2017, pp. 122 124. DOI: https://doi.org/10.1109/IVForum.20 17.8246068 .

[13] N. Vovchenko, A. Alukhanyan, L. Andreeva, G. Buryakov, Formation of an Adaptive Personnel Training System as a Factor of Ensuring Financial Stability of Leasing Companies. European Research Studies Journal 1 (2018) pp. 3-15. DOI: https://doi.org/10.35808/ersj/1153.

[14] E. Klochko, I. Bogdanov, I. Kobersy, M. Klimenkova, V. Litvinova, Research of organizational and economic resources, participants, cooperation of clusters in a certain territory. Espacios 31 (2018).

[15] E. Akhmetshin, K. Barmuta, Z. Yakovenko, L. Zadorozhnaya, D. Mironov, E. Klochko, Advantages of cluster approach in managing the economy of the Russian Federation. International Journal of Applied Business and Economic Research 23 (2017) pp. 355-364. 